\title{
Avoin korkeakoulu - kymmenen vuotta kokeilua ja kiistelyä
}

Suomen Kulttuurirahasto kutsui vuonna 1973 keskustelemaan joukon korkeakoululaitosta ja vapaata sivistystyötä lähellä olevia henkilöitä, jotka katsoivat avoimen yliopiston vaativan yksityiskohtaisempaa selvitystä. Rahaston asettama toimikunta jätti kahden vuoden työn jälkeen mietintönsä huhtikuussa 1976.

Nyt on huhtikuu 1986. Jännityksellä odotetaan, esittääkö hallitus eduskunnalle lisäbudjetissa määrärahan korkeakoulujen avoimeen korkeakouluopetukseen? Kanteleeko Helsingin Seudun Kesäyliopiston säätiö jälleen Jyväskylän yliopiston rahoitusratkaisusta? Esittääkö korkeakoulujen valintoja pohtiva toimikunta selkeätä ratkaisua, miten aikuisiällä voi päästä avoimien korkeakouluopintojen väylää tutkintoon johtavaan koulutukseen? Saadaanko ylipäätään kymmenen vuoden kokeilun ja kiistelyn jälkeen ratkaisuja, joilla pysyvästi turvataan aikuisväestön oikeus saada osallistua korkeakouluopetukseen?

SKR:n toimikunta pyrki valmistelemaan sellaista avointa korkeakoulua, joka pystyy koulu- ja nuorisoiän ohittaneelle ja nykyisen koulutusjärjestelmän ulkopuolelle jäävälle aikuisväestölle opettamaan tieteellistä ajattelutapaa, ja tiedon hankinnan ja luomisen taitoa sekä tarjoamaan mahdollisuuksia korkeakoulutasoiseen opiskeluun. Toteutuksen perusmuotona toimikunta piti korkeakoulujen ja vapaan sivistystyön välistä organisoitua yhteistyötä. Aina tutkintoon johtavien akateemisten opintojen suorittamisen lisäksi avoimen korkeakoulun tehtävänä tuli olla tieteen yleistajuistaminen ja "ehkä myös taiteen ymmärtämisen syventäminen".

Entä huhtikuussa 1986? Ovatko toimikunnan ehdotukset toteutuneet? Kymmenen vuotta on kokeiltu. Korkeakoulujen täydennyskoulutuskeskukset ovat pyrkineet erittäin niukoin voimavaroin kehittelemään toimikunnan hengen mukaisia uudenlaisia opetusjärjestelyjä (mm. etäopetus) ja parantamaan näin koulutuksen saavutettavuutta.

Kuitenkin avoin korkeakouluopetus on muutamia poikkeuksia lukuunottamatta erillisten korkeakouluopintojen välittämistä. Kesäyliopistot ovat hoitaneet opintojen välitystä 1950-luvulta lähtien kuntien rahoituksen, opiskelumaksujen, valtionavun ja korkeakoulujen tuntiopetusmäärärahojen turvin. Korkeakoulujen täydennyskoulutuskeskukset ovat voimavarojen puutteessa suunnanneet opetuksensa kansalais- ja työväenopistoihin.

Täydennyskoulutuskeskuksissa on tällä hetkellä noin 15000 ja kesäyliopistoissa noin 10000 sellaista aikuisopiskelijaa, jotka eivät ole minkään korkeakoulun varsinaisia opiskelijoita. Yhteismäärä on noin kolmannes korkeakoulujen varsinaisista opiskelijoista, joita lienee 75000.

Mikä on tämä uljas avoin korkeakoulu?

- Onko se hallinnollisrationaalinen kone, joka ylläpitää yhteyksiä, yhteistyötä ja välitystoimintaa?

- Onko koulutuksesta tehty hyödyke, joka markkinoidaan, välitetään ja kulutetaan kuin mikä tahansa tavara?

- Puhutaanko koulutuksellisista päämääristä, mutta toteutetaankin muita päämääriä? Kone esitellään poliittisille päätöksentekijöille hallinnollisesti joustavana ja taloudellisesti tehokkaana.

Moninaiset intressit ja välttämättömiksi katsotut yhteydet tekevät hal- 
linnosta erittäin monimutkaisen, koska toiminnalta puuttuu selvästi määritelty normisto, vastuu, työnjako ja organisointi. Tästä syystä esiintyy jatkuvaa kiistaa ja ristiriitaa kesäyliopistojen ja korkeakoulujen täydennyskoulutuskeskusten välillä. Tämä koneisto tuottaa vain niukasti itse koulutuksellista innovaatiota, kehittää opetusta tai sen sisältöjäa. Kone välittää sitä opetusta, joka yliopistojen laitoksilla on kertaalleen suunniteltu.

Pelkkä välitystoiminta ei aiheuta opetuksen suunnittelukustannuksia. Kaikki voimavarat voidaan kohdistaa mahdollisimman laajaan tarjontaan, mikä esitellään päätöksentekijöille tilastoissa osoituksena taloudellisesta tehokkuudesta. Sen sijaan välittäjillä ei ole vastuuta tarjonnan sisällöstä tai oppimisen tuloksista. Opetus, joka annetaan lukukauden aikana korkeakoulussa, saatetaan järjestää muutaman päivän aikana esim. kesällä. Kun tiedekunta on antanut ns. vastaavuuspäätöksen, suorituksilla on sama arvo kuin yliopistossa muutoinkin. Oppimisen ja opiskelun edellytysten turvaamiseksi on tehty vain vähän.

Avoimella korkeakouluopetuksella on kuitenkin suuri merkitys tuhansille aikuisopiskelijoille, jotka eivät tavoittele korkeakoulututkintoa tai edes halua muodollisia suorituksia. Syyt siihen, miksi mieluummin kuunnellaan illalla yliopiston luentosalissa sosiologian peruskurssia kuin pällistellään Dallasin sisällyksettömiä kiiltokuvia, ovat moninaiset. Vähäisin ei liene halu tieteellisen tiedon ja myös "taiteen ymmärtämisen syventämiseen', kuten kulttuurirahaston toimikunta avoimen korkeakoulun erään tavoitteen ilmaisi.

Kymmenessä vuodessa avoimen korkeakouluopetuksen perustaa ei ole kyetty rakentamaan, vaikka Kulttuurirahaston mietintö antoi hyvät piirustukset. Poliittisille päätöksentekijöille on ilmeisesti tarjottu käsitys, että korkeakoulupoliittista merkitystään yhäti lisäävä avoin korkeakoulu voidaan saada aikaan ilman keskitettyjä voimavaroja. Näin ei ole. Tieteelliset laitokset tarvitsevat opettajia, korkeakoulut aikuiskoulutuksen asiantuntijoita toiminnan kehittämiseen. Pélkät tuntiopetusmäärärahat eivät riitä, vaikka ne ovat tällä hetkellä välttämättömät, jotta toimintaa korkeakouluissa syksyllä 1986 voitaisiin jatkaa.

Sekä avoimen korkeakouluopetuksen organisointi-että rahoitusongelma ovat nousseet yhtäaikaa esille. Nyt on poliittisten päätöksentekijöiden otettava kanta kahteen kysymykseen:

1) Onko päävastuu avoimen korkeakouluopetuksen järjestämisestä korkeakouluilla ja niiden täydennyskoulutuskeskuksilla vai kesäyliopistoilla? Vastauksesta riippuu, tyydytäänkö vain välitystoimintaan vai päästäänkö Kulttuurirahaston toimikunnan esittämiin tavoitteisiin.

2) Maksavatko aikuisopiskefijat toiminnan kustannukset vai käytetäänkö niihin yhteiskunnan varoja * * tannukset peitetään yksinomaan maksuin eli maksullisena palvelutoimintana, avoin korkeakouluopetus irtaantuu yliopistojen perusyksiköistä, tieteellisistä laitoksista, joiden toimintaan sen tulisi entistä kiinteämmin kytkeytyä kuten ammatillisen täydennyskoulutuksenkin. Avoin korkeakouluopetus ei pitkään voi olla opettajien selkänahasta revittyä ylimääräistä työtä, vaan sen tulisi olla opetusvelvollisuutena ja tuntiopetusmäärärahoin annettavaa opetusta kuten muukin yliopiston opetus.

Avoin korkeakoulu on osa yleismaailmallista korkeakoulujen laajennusliikettä. Korkeimman opetuksen alueellinen ja määrällinen laajeneminen tapahtui 1960-70 -luvuilla. Nyt laajentuminen ilmenee uusien ryhmien mukaantulona, uusien opetusjärjestelyjen kehittelynä ja tieteellisen tiedon ja ajattelun hankkimisena myös aikuisiällä. Suomen Kulttuurirahaston toimikunta viitoitti tien korkeakoulujen aikuiskoulutukselle, kymmenen vuotta on kokeiltu. Nyt on vakavan kehittämistyön aika.

Jorma Taskinen 